\title{
Response of Salt-Stressed Wheat(Triticum aestivum L.) to Potassium Humate Treatment and Potassium Silicate Foliar Application
}

\author{
M. E.H. Osman, Awatif A. Mohsen, Soad S. El-Feky and Walaa A. Mohamed \\ Botany Department, Faculty of Science, Tanta University, Tanta, Egypt.
}

\begin{abstract}
T HE PRESENT study was carried out to investigate the effect of high $\mathrm{NaCl}$ concentrations on some growth parameters and physiological processes of wheat (Triticum aestivum L.) plant. The results indicated that Gemeza.9 was the most sensitive cultivar to high salinity levels compared to all tested wheat cultivars. Moreover, salinity stress caused a reduction in the germination percentage by $65 \%$ and all growth parameters by $21 \%, 25 \%$ and $60 \%$ in the lengths of shoot, root and leaf area, also by $27 \%$ and $48 \%$ in fresh weights of shoot, root and $40 \%$ and $75 \%$ in dry weights of shoot and root. It also increased the activity of antioxidant enzymes (peroxidase and catalase), lipid peroxidation and ascorbic acid content. Salinity induced increase of osmolytes compounds such as total soluble proteins, carbohydrates and amino acids. Furthermore, all measured yield parameters, the percentage of grain's maturity and productivity were highly decreased. Accordingly, the role of potassium humate and potassium silicate either sole or combined in alleviating the toxic effect of salinity was also studied. Results showed that application of potassium humate as sole had a stimulatory effect higher than potassium silicate or their combination. It increased the germinating percentage by $128 \%$ at $200 \mathrm{mM} \mathrm{NaCl}$. In addition, potassium humate and potassium silicate increased the photosynthetic activity, decreased the activity antioxidant enzymes (Peroxidase and Catalase) as well as biosynthesis of MDA and ascorbic acid also they induced increase biosynthesis of proteins and carbohydrates in yielded grains. Accordingly, our study recommends the application of potassium humate as an organic fertilizer and potassium silicate as a foliar spray for improving the quality and quantity of the sensitive wheat cultivar Gemeza.9 cultivated in salty lands and increases its productivity.
\end{abstract}

Keywords: Salinity, Amelioration, Foliar application, Potassium Humate, Potassium Silicate.

\section{Introduction}

Wheat (Triticum aestivum L.) is the second most important food crop after rice (Malav et al., 2017). Wheat is considered as one of the most important edible crops in Egypt. It provides approximately one-fifth of the total caloric input of the world's population (FAO, 2010). In wheat grains, starch is present in large amounts (60-68\%) where, it is considered the most important reserve polysaccharide of many types of cereals (Parker \& Ring, 2001). Moreover, wheat grains contain protein $(6-21 \%)$, fats $(1.5-2.0 \%)$, cellulose $(2.0$ $2.5 \%$ ), minerals $(1.8 \%)$ and vitamins (Das, 2008 and Malav et al., 2017). Egypt remains the world's largest wheat importer. Egypt imported about 12 million tons of wheat in 2016/2017, this estimation about 1.3 million tons above the average for the last five years (FAO, 2016). Many efforts should be directed toward increasing cultivating wheat in Egypt to fill the gap between production and consumption (Kandil et al., 2016).
Soil salinity is a global problem that adversely affects $20 \%$ of irrigated land and reduces crop yields (Qadir et al., 2014). It results in ion toxicity, osmotic and oxidative stress, nutritional imbalances, reduction of cell divisions and alterations in metabolic processes as photosynthesis, respiration, and disorganization of membranes of plants (Sen et al., 2002 and Hasanuzzaman et al., 2014). Many investigators have reported the reduction of plant growth due to salinity stress.

The addition of supplemental organic matters of different sources acts as an ameliorative agent against salinity stress (Walker \& Bernal, 2008). Humic substances (humates, humic acids, and fulvic acids) make up the bulk of humus which resulted from organic soil decomposition and constituting $65-75 \%$ of organic matters (Shahryari et al., 2009). Potassium humate is an effective fertilizer that positively affects growth, yield and

"Corresponding author email: walaa_abd_elmegeid@yahoo.com

DOI: $10.21608 /$ ejbo.2017.1070.1094

C2017 National Information and Documentation Centre (NIDOC) 
chemical constituents of wheat plant (Kandil et al., 2016). Potassium humate increases the rate of nutrient uptake, enhances plant biomass and reduces the soil compaction (Canellas et al., 2015).

On other hands, foliar spraying of plants with micronutrient elements increases plant's tolerance under salinity stress (Van Bockhaven et al., 2013). Between all the micronutrients assimilation by plants, silicon is considered as the same macronutrients concentration needed by plants (Ahmad et al., 2013). Silicon has the ability to ameliorate salt stress due to its high efficiency to increase relative water content, membrane stability index, antioxidant enzyme activity such as peroxidase and catalase and decline proline content so it's foliar application in the form of silicate liquid solutions can be used as a promising alternative to mitigate abiotic stress-induced damage in wheat (Sapre \& Vakharia, 2017).

Therefore, the objective of this work was to detect the effect of salinity stress on growth and yield of wheat (Triticum aestivum L.) and assessing the role of potassium humate and potassium silicate on alleviating the deleterious effect of salinity.

\section{Materials and Methods}

\section{Germination percentage}

This experiment was carried out in small plastic pots $\left(15 \mathrm{~cm}^{2}\right.$ diameter and $10 \mathrm{~cm}$ depth), each one was filled with $5 \mathrm{~kg}$ clay-sandy soil $(2: 1 \mathrm{w} / \mathrm{w}), 10$ grains were sown in each pot for each treatment and was replicated 3 times, the different concentrations of $\mathrm{NaCl}$ were prepared $(0,50,100,150,200,250,300,350,400,400$ and $450 \mathrm{mM}$ ) for determination the lethal and sublethal level of $\mathrm{NaCl}$. Pots were irrigated with $\mathrm{NaCl}$ solutions for 7 days. Gemeza.9 cultivar was chosen as the most sensitive one at $200 \mathrm{mM}$ $\mathrm{NaCl}$ as sublethal level to be used in the present study.

To determine the germination percentage of wheat grains ( cv. Gemeza.9) which treated with potassium humate, pots were divided into two groups then irrigated with $\mathrm{NaCl}$ concentrations (0-200mM); the second group was irrigated with $\mathrm{NaCl}$ concentrations and potassium humate $(0.02$ $\mathrm{g} /$ Pot, $1 \mathrm{~kg} / \mathrm{fad}$ ) and left in the environmental conditions for 7 days.
Plant material, growth conditions, and treatments Wheat grains (Triticum aestivum L., cv.Gemeza.9) were selected for uniformity in size and shape, washed several times with distilled water and grown in clay sandy soil (2:1 $\mathrm{w} / \mathrm{w})$ in plastic pots $\left(40 \mathrm{~cm}^{2}\right.$ diameter, $45 \mathrm{~cm}$ depth).The experiments were carried out during the growing season of wheat i.e. from December to end of March. Pots were divided into four groups then irrigated with (80\% field capacity). The seedlings were left to grow for 7 days under normal environmental conditions at $29 \pm 2^{\circ} \mathrm{C}$ during the day and $12 \pm 2^{\circ} \mathrm{C}$ during the night. On the $8^{\text {th }}$ day, the first group was irrigated with $\mathrm{NaCl}$ (0-200 mM) while the second group was treated with the recommended dose of potassium humate (Pot.H) (0.2 g/Pot, $1 \mathrm{~kg} / \mathrm{fad})$. Moreover, the third group was sprayed with $25 \%$ potassium silicate (Pot.Si) (250 mg/L Sio 2 ) according to the recommended dose. Finally, the fourth group was treated with a combination of them. Samples were collected after 30 days (seedling stage), 60 days (vegetative stage) and 120 days (yield stage) and subjected to the following experiments.

\section{Photosynthetic activity and pigments}

Photosynthetic activity (Fv/Fm) of darkadapted leaves was measured with OS-30p chlorophyll fluorometer (Hudson, NH 03051 USA). The photosynthetic pigments, chlorophyll a (Chl.a), chlorophyll b (Chl.b) and carotenoids were assayed according to Arnon (1949) and expressed as $\mathrm{mg} \mathrm{g}^{-1}$ dry weight.

\section{Enzymes extractions and assays}

A sample of $0.5 \mathrm{~g}$ fresh leaves was frozen and then homogenized in $8 \mathrm{ml}$ of $50 \mathrm{mM}$ cold phosphate buffer ( $\mathrm{pH}$ 7.0) (Beauchamp $\&$ Fridovich, 1971). The homogenates were centrifuged at $4000 \mathrm{rpm}$ at $4^{\mathrm{C}^{\circ}}$ for $20 \mathrm{~min}$. The supernatant was used as a raw extract for enzymatic assay. Activities of catalase [EC1.11.1.6] and peroxidase [EC1.11.1.7] were assayed according to Kato \& Shimizu (1987). Enzyme activity was expressed in units of $\mu \mathrm{M}$ of the substrate converted per min. per gram fresh weight

\section{Lipid MDA and ascorbic acid content}

Lipid peroxidation level was measured by determining malondialdehyde (MDA) content (peroxidation product). MDA content was estimated according to Heath \& Packer (1968) and calculated using the extinction coefficient 
(155 $\left.\mathrm{mM}^{-1} \mathrm{~cm}^{-1}\right)$ and expressed as $\mu \mathrm{molg}^{-1}$ fresh weight. Ascorbic acid was estimated according to Oser (1979). Ascorbic acid content was calculated as $\mathrm{mg}^{-1}$ fresh weight by using a calibration curve.

\section{Total soluble protein and carbohydrates}

The phenol-sulfuric acid method has been used to estimate the total soluble carbohydrates using a calibration curve according to Dubois et al. (1956). Total soluble protein content was estimated quantitatively using phosphate buffer ( $\mathrm{pH} 7$ ) extract using a calibration curve by Bovine serum albumin (BSA) as a standard protein according to Bradford (1976). They are expressed as $\mathrm{mg} \mathrm{g}^{-1}$ dry weight.

\section{Total amino acids and proline content}

Amino acids content was assayed using ninhydrin and glycine as a standard according to Lee \& Takahashi (1966). Proline was estimated according to Zungia et al. (1989) and Bates (1973) by using toluene as a blank. They are calculated as $\mathrm{mg} \mathrm{g}^{-1}$ dry weight.

\section{Statistical analysis}

The results were analyzed statistically using one-way (ANOVA) test to determine the degree of significance. The analysis was carried out using COSTAT statistical program. In addition to correlation coefficient $\left(\mathrm{R}^{2}\right)$ were applied for investigating the significance of the relationships between the studied variables of plant the analysis was carried out by SPSS (v.6.12).

\section{Results}

Preliminary experiment

Data shown in Table 1 indicates that increasing $\mathrm{NaCl}$ concentrations decreased the germination percentage except at $50 \mathrm{mM}$ conc. the germination percentage has no effect compared with the control. As shown that Sakha.93 is the most tolerant cultivar while Gemeza.9 is the most sensitive one (Table 1).

\section{Germinating percentage}

Results in Table 2 indicate that treating wheat grains (cv.Gemeza.9) with high salinity level $(200 \mathrm{mM} \mathrm{NaCl})$ resulted in a reduction of germination percentages by $65 \%$ compared with the control. However, the germination percentage of all treated samples with potassium humate was increased and at high salinity level $(200 \mathrm{mM} \mathrm{NaCl})$ the percentage was increased by $128 \%$ compared with saltstressed samples (Table 2).

TABLE 1. Effect of different concentrations of $\mathrm{NaCl}(0-450 \mathrm{mM})$ on the germination percentage of different 7-day-old Triticum aestivum L. cultivars grains grown in clay sandy soil (2:1w/w).

\begin{tabular}{|c|c|c|c|c|c|c|}
\hline \multirow{2}{*}{$\begin{array}{l}\text { Conc. of } \mathrm{NaCl} \\
(\mathrm{mM})\end{array}$} & \multicolumn{6}{|c|}{ Germination percentage } \\
\hline & Sakha. 93 & Giza.168 & Misr.1 & Sods.12 & Gemeza.11 & Gemeza.9 \\
\hline 0 & $99 \pm 1 \mathrm{~g}$ & $99 \pm 1^{\mathrm{g}}$ & $99 \pm 1^{f}$ & $99 \pm 1^{\mathrm{f}}$ & $99 \pm 1^{\mathrm{g}}$ & $99 \pm 1^{\mathrm{e}}$ \\
\hline 50 & $99 \pm 1^{\mathrm{g}}$ & $99 \pm 1^{\mathrm{g}}$ & $99 \pm 1^{\mathrm{f}}$ & $99 \pm 1^{\mathrm{f}}$ & $99 \pm 1^{\mathrm{g}}$ & $99 \pm 1^{\mathrm{e}}$ \\
\hline 100 & $98 \pm 1^{g}$ & $95 \pm 3 \mathrm{~g}$ & $85 \pm 3^{e}$ & $95 \pm 3^{f}$ & $85 \pm 3^{f}$ & $70 \pm 3^{d}$ \\
\hline 150 & $75 \pm 3^{f}$ & $85 \pm 3^{f}$ & $70 \pm 2^{d}$ & $65 \pm 3^{e}$ & $75 \pm 3^{\mathrm{e}}$ & $60 \pm 2^{c}$ \\
\hline 200 & $65 \pm 3^{\mathrm{e}}$ & $70 \pm 3^{e}$ & $50 \pm 2^{c}$ & $45 \pm 2^{\mathrm{d}}$ & $50 \pm 2^{d}$ & $35 \pm 2^{b}$ \\
\hline 250 & $50 \pm 2^{d}$ & $50 \pm 2^{d}$ & $45 \pm 2^{c}$ & $35 \pm 2^{c}$ & $40 \pm 2^{c}$ & $00.0^{\mathrm{a}}$ \\
\hline 300 & $45 \pm 2^{\mathrm{d}}$ & $35 \pm 2^{c}$ & $35 \pm 1 \mathrm{~b}$ & $25 \pm 1 \mathrm{~b}$ & $35 \pm 2^{b}$ & $00.0^{\mathrm{a}}$ \\
\hline 350 & $35 \pm 2^{c}$ & $25 \pm 1^{b}$ & $00.0^{\mathrm{a}}$ & $00.0^{a}$ & $00.0^{\mathrm{a}}$ & $00.0^{\mathrm{a}}$ \\
\hline 400 & $20 \pm 1^{b}$ & $00.0^{\mathrm{a}}$ & $00.0^{a}$ & $00.0^{\mathrm{a}}$ & $00.0^{\mathrm{a}}$ & $00.0^{\mathrm{a}}$ \\
\hline 450 & $00.0^{a}$ & $00.0^{\mathrm{a}}$ & $00.0^{a}$ & $00.0^{\mathrm{a}}$ & $00.0^{\mathrm{a}}$ & $00.0^{\mathrm{a}}$ \\
\hline $\mathrm{R}^{2}$ & $99.41 \%$ & $97.99 \%$ & $96.31 \%$ & $96.81 \%$ & $96.21 \%$ & $95.94 \%$ \\
\hline $\mathrm{P}$-value & \multicolumn{6}{|c|}{$0.0001 * * *$} \\
\hline
\end{tabular}

Values are the mean of three replicates $\pm \mathrm{SD}$, Values within the same column for each factor designed by the same letter are insignificant $(\mathrm{p} \leq 0.05)$, Values with different letters are significant $(\mathrm{p} \leq 0.05)$ 
TABLE 2. Effect of different concentrations of $\mathrm{NaCl}(0-200 \mathrm{mM})$ on the germination percentage of 7-day-old Triticum aestivum L. (cv.Gemeza.9) grains grown in clay sandy soil (2:1w/w) after soil supplementation with potassium humate (Pot.H) $(0.02 \mathrm{~g} / \mathrm{Pot}, 1 \mathrm{~kg} / \mathrm{fad})$.

\begin{tabular}{lcc}
\hline $\begin{array}{l}\text { Conc. of NaCl } \\
(\mathbf{m M})\end{array}$ & \multicolumn{2}{c}{$\begin{array}{c}\text { Germination percentage } \\
\text { Pot.H } \\
\mathbf{( 0 . 0 2} \mathbf{g} / \mathbf{p o t}, \mathbf{1} \mathbf{k g} / \mathbf{f a d})\end{array}$} \\
\hline 0 & Non-treated & $99 \pm 1^{\mathrm{b}}$ \\
50 & $99 \pm 1^{\mathrm{d}}$ & $99 \pm 1^{\mathrm{b}}$ \\
100 & $99 \pm 1^{\mathrm{d}}$ & $95 \pm 3^{\mathrm{b}}$ \\
150 & $70 \pm 3^{\mathrm{c}}$ & $85 \pm 2^{\mathrm{a}}$ \\
200 & $60 \pm 2^{\mathrm{b}}$ & $80 \pm 2^{\mathrm{a}}$ \\
$\mathrm{R}^{2}$ & $35 \pm 2^{\mathrm{a}}$ & $99.84 \%$ \\
P-value & $96.33^{\mathrm{a}} \%$ & \\
\hline
\end{tabular}

Values are the mean of three replicates $\pm \mathrm{SD}$, Values within the same column for each factor designed by the same letter are insignificant $(\mathrm{p} \leq 0.05)$, Values with different letters are significant $(\mathrm{p} \leq 0.05)$.

\section{Main experiment}

Growth parameters

Table 3 indicates that at $200 \mathrm{mM} \mathrm{NaCl}$, all the measured growth parameters of the seedlings decreased by $21 \%, 25 \%$ and $60 \%$ in the lengths of shoot, root and leaf area, respectively compared with the control. However, the reduction reached $27 \%$ and $48 \%$ in fresh weights of shoot, root and $40 \%$ and $75 \%$ in dry weights of shoot and root, respectively compared to control. Data presented in Table 3 also show that all growth parameters of seedlings (the lengths of shoot, root and leaf area) and (fresh and dry weights of shoot and root) increased by treating with potassium humate as sole $(15 \%, 27 \%$ and $90 \%)$ and $(20 \%, 33 \%, 28 \%$ and $200 \%$ ), respectively compared with control while application of potassium silicate only increased all of them $(4 \%, 9 \%$ and $45 \%),(7 \%$, $12 \%, 15 \%$ and $100 \%)$, respectively compared with control. Accordingly, the combination of potassium humate and silicate approximately has the same effect of potassium silicate (Table 3).

TABLE 3. Effect of different concentrations of $\mathrm{NaCl}(0-200 \mathrm{mM})$ on some growth parameters of 30-day-old Triticum aestivum L. (cv.Gemeza.9) seedlings grown in clay sandy soil $(2: 1 \mathrm{w} / \mathrm{w})$, in response to soil irrigation at $(80 \%$ field capacity) followed by soil supplementation with potassium humate (Pot.H) $(0.2 \mathrm{~g} / \mathrm{pot}, 1 \mathrm{~kg} / \mathrm{fad})$ and spraying using potassium silicate (Pot.Si) $\left(250 \mathrm{mg} / \mathrm{L} \mathrm{SiO}_{2}\right)$ as sole or combined.

\begin{tabular}{|c|c|c|c|c|c|c|c|}
\hline \multirow[t]{2}{*}{ Treatment } & \multicolumn{2}{|c|}{$\begin{array}{c}\text { Length } \\
\text { (cm/organ) }\end{array}$} & \multicolumn{2}{|c|}{$\begin{array}{l}\text { Fresh weight } \\
\text { (g/organ) }\end{array}$} & \multicolumn{2}{|c|}{$\begin{array}{l}\text { Dry weight } \\
\text { (g/organ) }\end{array}$} & \multirow{2}{*}{$\begin{array}{l}\text { Leaf area } \\
\left(\mathrm{cm}^{2} / \mathrm{leaf}\right)\end{array}$} \\
\hline & Shoot & Root & Shoot & Root & Shoot & Root & \\
\hline Control & $17.1 \pm 0.1^{\mathrm{d}}$ & $15.1 \pm 0.3^{\mathrm{e}}$ & $1.34 \pm 0.01^{\mathrm{d}}$ & $0.25 \pm 0.001^{\mathrm{e}}$ & $0.20 \pm 0.001^{\mathrm{c}}$ & $0.04 \pm 0.002^{\mathrm{e}}$ & $2.8 \pm 0.2^{\mathrm{d}}$ \\
\hline $\begin{array}{l}200 \mathrm{mM} \\
\mathrm{NaCl}\end{array}$ & $13.4 \pm 0.1^{\mathrm{a}}$ & $11.3 \pm 0.4^{\mathrm{a}}$ & $0.97 \pm 0.05^{\mathrm{a}}$ & $0.13 \pm 0.005^{\mathrm{a}}$ & $0.12 \pm 0.005^{\mathrm{ab}}$ & $0.01 \pm 0.001^{\mathrm{a}}$ & $1.1 \pm 0.1^{\mathrm{a}}$ \\
\hline $\begin{array}{l}\text { Pot.H } \\
(0.2 \mathrm{~g} / \text { pot }, 1 \mathrm{~kg} / \\
\text { fad })\end{array}$ & $19.8 \pm 0.1^{\mathrm{g}}$ & $18.4 \pm 0.2^{\mathrm{h}}$ & $1.97 \pm 0.01^{\mathrm{f}}$ & $0.32 \pm 0.001^{\mathrm{h}}$ & $0.29 \pm 0.001^{\mathrm{d}}$ & $0.06 \pm 0.002^{\mathrm{g}}$ & $4.3 \pm 0.3^{\mathrm{f}}$ \\
\hline $\begin{array}{l}\text { Pot. } \mathrm{H}+200 \\
\mathrm{mM} \mathrm{NaCl}\end{array}$ & $15.4 \pm 0.4^{\mathrm{c}}$ & $14.4 \pm 0.2^{\mathrm{d}}$ & $1.17 \pm 0.05^{\mathrm{c}}$ & $0.18 \pm 0.005^{\mathrm{c}}$ & $0.16 \pm 0.005^{\mathrm{b}}$ & $0.03 \pm 0.001^{\mathrm{d}}$ & $2.1 \pm 0.1^{\mathrm{c}}$ \\
\hline $\begin{array}{l}\text { Pot.Si } \\
\left(250 \mathrm{mg} / \mathrm{L} \mathrm{SiO}_{2}\right)\end{array}$ & $18.3 \pm 0.3^{\mathrm{e}}$ & $16.2 \pm 0.4^{\mathrm{f}}$ & $1.45 \pm 0.01^{\mathrm{e}}$ & $0.28 \pm 0.001^{\mathrm{f}}$ & $0.26 \pm 0.001^{\mathrm{d}}$ & $0.05 \pm 0.002^{\mathrm{e}}$ & $3.3 \pm 0.2^{\mathrm{e}}$ \\
\hline $\begin{array}{l}\text { Pot.Si+200 } \\
\mathrm{mM} \mathrm{NaCl}\end{array}$ & $13.9 \pm 0.5^{\mathrm{a}}$ & $12.3 \pm 0.2^{b}$ & $1.04 \pm 0.05^{\mathrm{b}}$ & $0.15 \pm 0.005^{\mathrm{b}}$ & $0.14 \pm 0.005^{\mathrm{ab}}$ & $0.02 \pm 0.001^{\mathrm{b}}$ & $1.6 \pm 0.1^{\mathrm{b}}$ \\
\hline Pot.H+Pot.Si & $18.9 \pm 0.5^{f}$ & $17.3 \pm 0.3^{\mathrm{g}}$ & $1.46 \pm 0.01^{\mathrm{e}}$ & $0.30 \pm 0.001^{g}$ & $0.27 \pm 0.001^{\mathrm{d}}$ & $0.05 \pm 0.002^{\mathrm{f}}$ & $3.9 \pm 0.2^{\mathrm{f}}$ \\
\hline $\begin{array}{l}\text { Pot.H+Pot.Si } \\
+200 \mathrm{mM} \mathrm{NaCl}\end{array}$ & $14.6 \pm 0.2^{\mathrm{b}}$ & $13.1 \pm 0.3^{c}$ & $1.06 \pm 0.05^{\mathrm{b}}$ & $0.16 \pm 0.005^{\mathrm{c}}$ & $0.14 \pm 0.005^{\mathrm{a}}$ & $0.03 \pm 0.001^{\mathrm{c}}$ & $1.7 \pm 0.1^{\mathrm{b}}$ \\
\hline $\mathrm{R}^{2}$ & $96.13 \%$ & $95.84 \%$ & $97.22 \%$ & $96.51 \%$ & $96.81 \%$ & $99.21 \%$ & $98.94 \%$ \\
\hline P-value & & & & $0.0001 * * *$ & & & \\
\hline
\end{tabular}

Values are the mean of three replicates $\pm \mathrm{SD}$, Values within the same column for each factor designed by the same letter are insignificant $(\mathrm{p} \leq 0.05)$, Values with different letters are significant $(\mathrm{p} \leq 0.05)$. 


\section{Biochemical analysis \\ Photosynthetic activity and photosynthetic pigments}

Salinity resulted in a negative effect on photosynthetic activity and photosynthetic pigments content (Fig.1). High salinity level $(200 \mathrm{mM} \mathrm{NaCl})$ caused a marked reduction in photosynthetic efficiency $(30 \%)$ compared with the control and caused a high reduction in photosynthetic pigments (Chl.a and Chl.b) by (44\% and $87 \%$ ), respectively and increased carotenoids by $94 \%$ compared with control. Results in Fig.1 indicate that application of potassium humate and potassium silicate either sole or combined decreased the negative effects of salinity. However, application of potassium humate as sole was more efficient than potassium silicate or their combination whereas; it increased the photosynthetic activity by $25 \%$ and pigments content (Chl.a and Chl.b) by 50\% and 414\%, respectively compared with control. Accordingly, potassium silicate increased the photosynthetic activity by $13 \%$ and pigments contents (Chl.a and Chl.b) by $24 \%$ and $271 \%$, respectively compared with control. However, potassium humate and potassium silicate separately or combined expressed similar effect in reducing carotenoids $(18 \%$ and $15 \%)$, respectively compared with control.

Antioxidant enzymes, lipid peroxidation and ascorbic acid content

Results in Fig.2 show that the activity of both peroxidase and catalase enzymes were significantly enhanced in response to salinity stress. The percentages of increase were $55 \%$ and $60 \%$, for peroxidase and catalase, respectively relative to the control. Similarly, ascorbic acid and the malondialdehyde (MDA) content were highly increased in salt-stressed seedlings by $57 \%$ and $215 \%$, respectively compared with the control. Data in Fig. 2 indicates that potassium humate, potassium silicate and their combination caused a significant reduction in peroxidase and catalase activities and the contents of ascorbic acid and MDA. However, application of potassium humate as sole was more efficient in reducing peroxidase and catalase activities by $32 \%$ and $25 \%$, respectively. The content of ascorbic acid was decreased by $26 \%$ and MDA by $61 \%$ compared to control. Accordingly, potassium silicate reduced the activities of peroxidase and catalase enzymes by $22 \%$ and 12.5 , respectively and the contents of ascorbic acid and MDA by $17 \%$ and $36 \%$, respectively compared with control. The combination of potassium humate and potassium silicate treatments has the same effect of potassium silicate.

\section{Total soluble proteins and carbohydrates}

Data in Fig.3 indicates that high salinity level $(200 \mathrm{mM} \mathrm{NaCl})$ caused a significant increase in total soluble proteins and carbohydrates content, the increase reached $300 \%$ and $250 \%$, respectively relative to the control. Application of potassium humate, potassium silicate and their combination increased the total soluble proteins and carbohydrates compared with control. However, potassium humate as sole was significantly decreased total soluble proteins and carbohydrates content by $38 \%$ and $35 \%$, respectively while potassium silicate single and combined with potassium humate has the same effect in reducing both total soluble proteins and carbohydrates by $18 \%$ and $28 \%$, respectively compared with untreated seedlings.

Total soluble amino acids and proline content

Data in Fig.4 shows that treatment with $(200 \mathrm{mM}$ $\mathrm{NaCl}$ ) caused a highly significant increase in the total soluble amino acids by $160 \%$ and proline content by $200 \%$ relative to the control. However, potassium humate and potassium silicate and their combination approximately have the same effect in decreasing contents of total soluble amino acids and proline whereas; they decreased total soluble amino acids by $44 \%$ and $23 \%$, respectively as well as decreased proline content with $87 \%$ and $86 \%$ compared with control.

\section{Yield parameters}

Table 4 shows that the salinity $(200 \mathrm{mM} \mathrm{NaCl})$ caused a significant decrease of all the measured yield parameters (spike length, the number of spikes/ plant, and the number of spikelet/ plant, spike weight, the number of grains/spike, and weight of 1000 grains). As shown in Table 4 that salinity decreased the number of spikes/plant, the number of grains/spike, and weight of 1000 grains with $75 \%$, $68 \%$, and $64 \%$, respectively compared with control. However, applications of potassium humate and potassium silicate as sole or combined increased all measured yield parameters. Accordingly, potassium humate was more efficient than potassium silicate and their combination in enhancing the productivity and maturity where, the percentage of maturity reached to $80 \%$ and weight of thousand grains increased by $155 \%$ compared with control. While potassium silicate increased the productivity (weight of 1000 grains) by $120 \%$ compared with control. On other hands, potassium humate increased weight of thousand grains by $65 \%$ while potassium silicate and the combination increased it by $14 \%$ and $17 \%$, respectively relative with control (Table 4). 


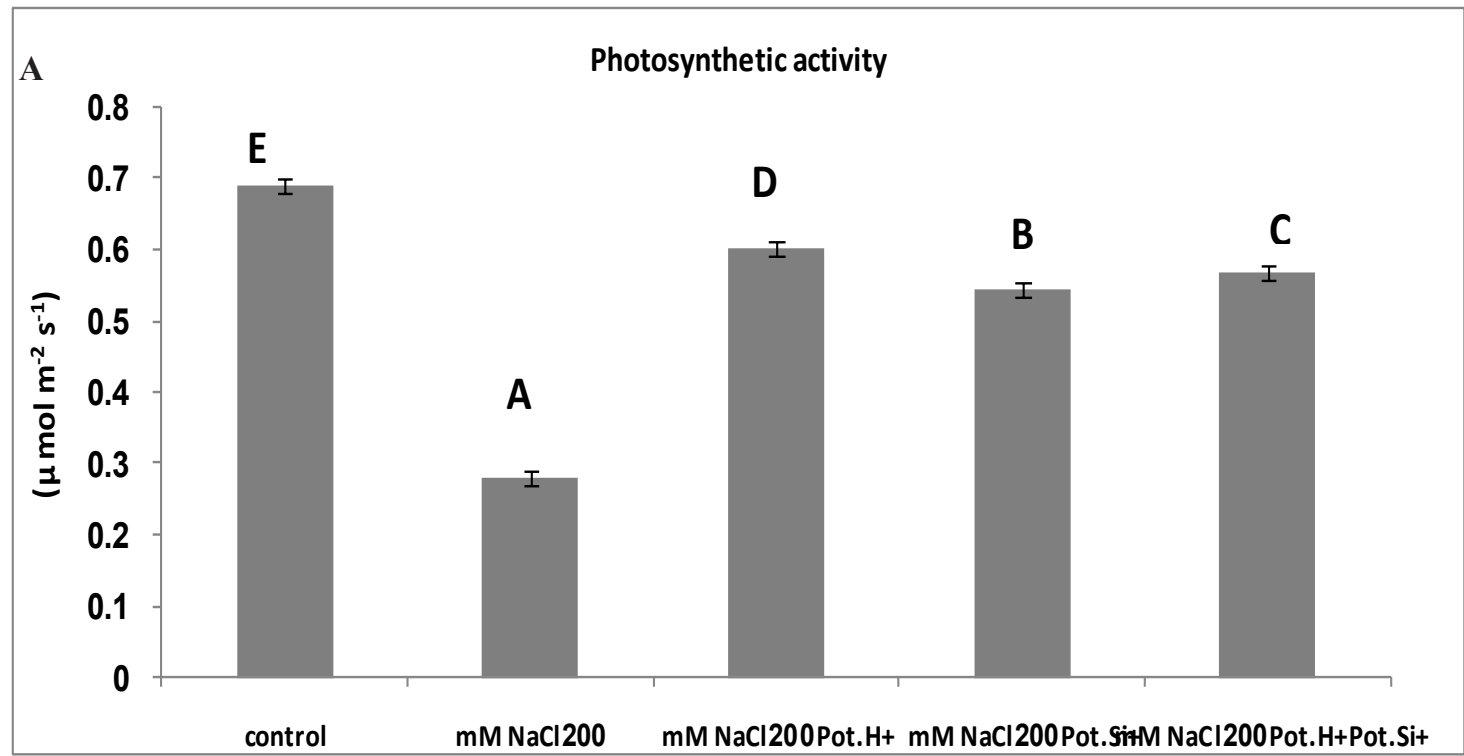

B

control

mM NaCl200

7) $\mathrm{mM} \mathrm{NaCl200Pot.H+}$

InM NaCl200Pot.Si+

s mM NaCl200Pot.H+Pot.Si+

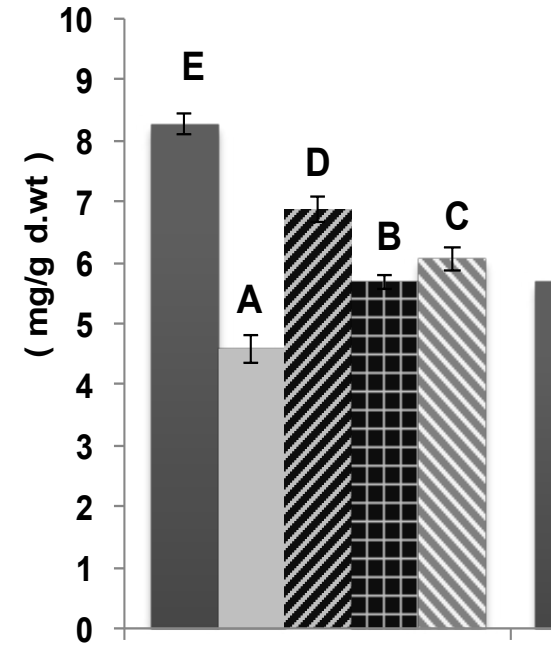

Chl.a

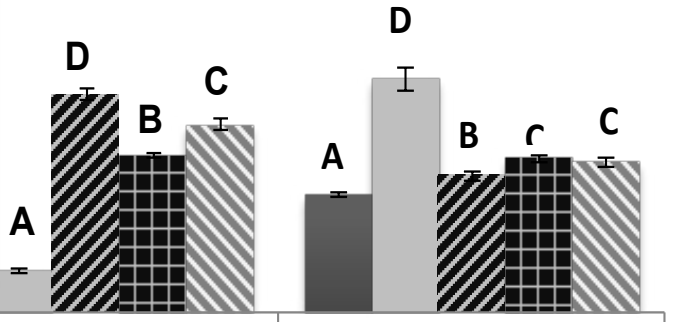

Carotenoids

Fig.1. Effect ofdifferent concentrations of $\mathrm{NaCl}(0-200 \mathrm{mM})$ on photosynthetic activity (Fv/Fm) (A) and photosynthetic pigments (Chl.a, Chl.b and carotenoids) (B) of 30-day-old Triticum aestivum L. (cv.Gemeza.9) seedlings grown in clay sandy soil $(2: 1 \mathrm{w} / \mathrm{w})$, in response to soil irrigation at ( $80 \%$ field capacity) followed by soil supplementation with potassium humate (Pot.H) $(0.2 \mathrm{~g} / \mathrm{pot}, 1 \mathrm{~kg} / \mathrm{fad})$ and spraying using potassium silicate (Pot.Si) $\left(250 \mathrm{mg} / \mathrm{L} \mathrm{SiO}_{2}\right)$ as sole or combined. Values are the mean of three replicates $\pm \mathrm{SD}$, Values within the same column for each factordesigned by the same letter are insignificant $(p \leq 0.05)$, Values with different letters are significant $(p \leq 0.05)$ 

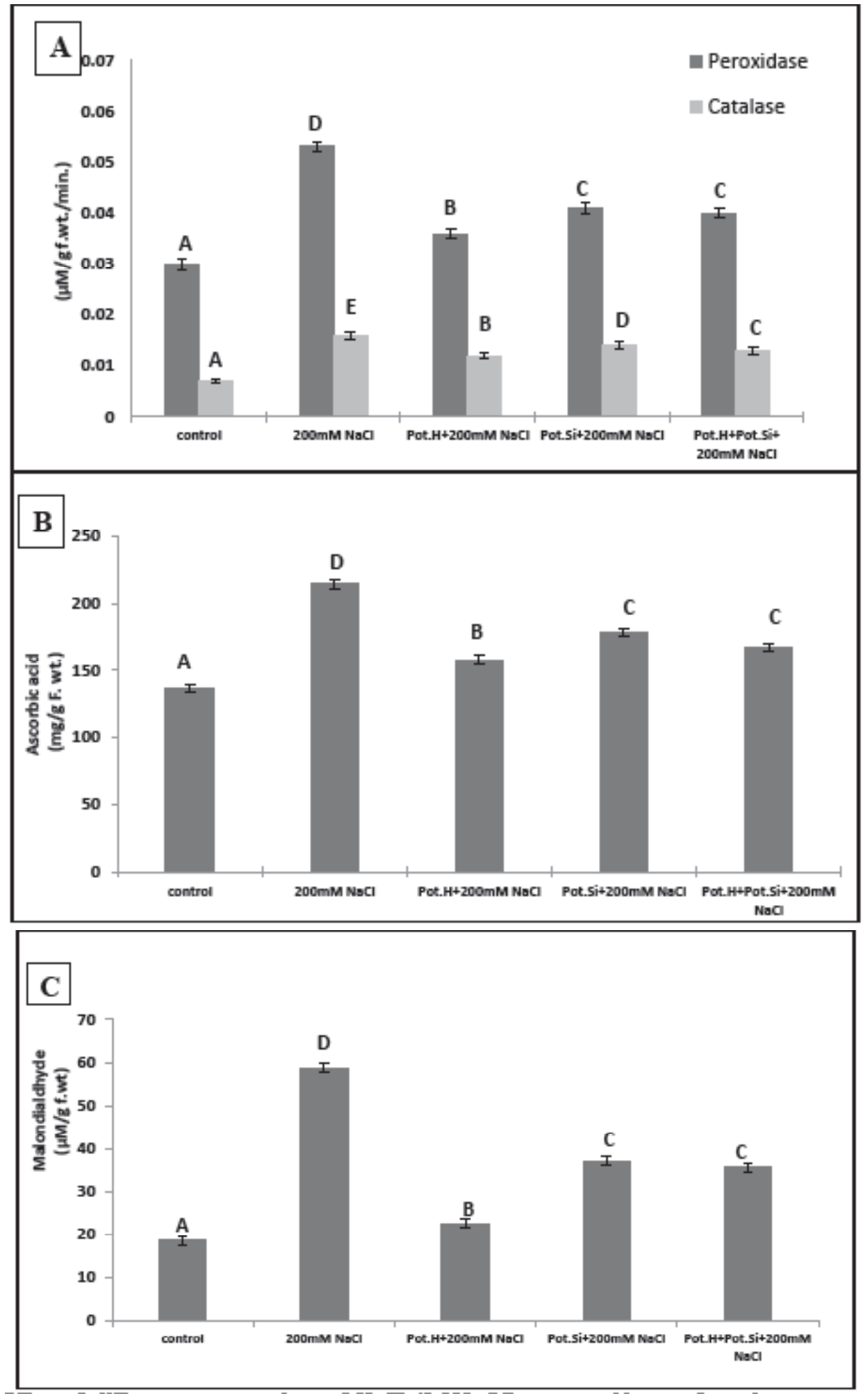

Fig.2. Effect of different concentrations of $\mathrm{NaCl}(0-200 \mathrm{mM})$ on peroxidase and catalase enzyme (A) and ascorbic acid (B) and MDA (C) contents of 30-day-old Triticum aestivum L. (cv.Gemeza.9) seedlings grown in clay sandy soil $(2: 1 \mathrm{w} / \mathrm{w})$, in response to soil irrigation at $(80 \%$ field capacity) followed by soil supplementation with potassium humate (Pot.H) $(0.2 \mathrm{~g} / \mathrm{pot}, 1 \mathrm{~kg} / \mathrm{fad})$ and spraying using potassium silicate (Pot.Si) $(250 \mathrm{mg} / \mathrm{L}$ $\mathrm{SiO}_{2}$ ) as sole or combined. Values are the mean of three replicates $\pm \mathrm{SD}$, Values within the same column for each factor designed by the same letter are insignificant $(p \leq 0.05)$, Values with different letters are significant $(\mathbf{p} \leq \mathbf{0 . 0 5})$ 


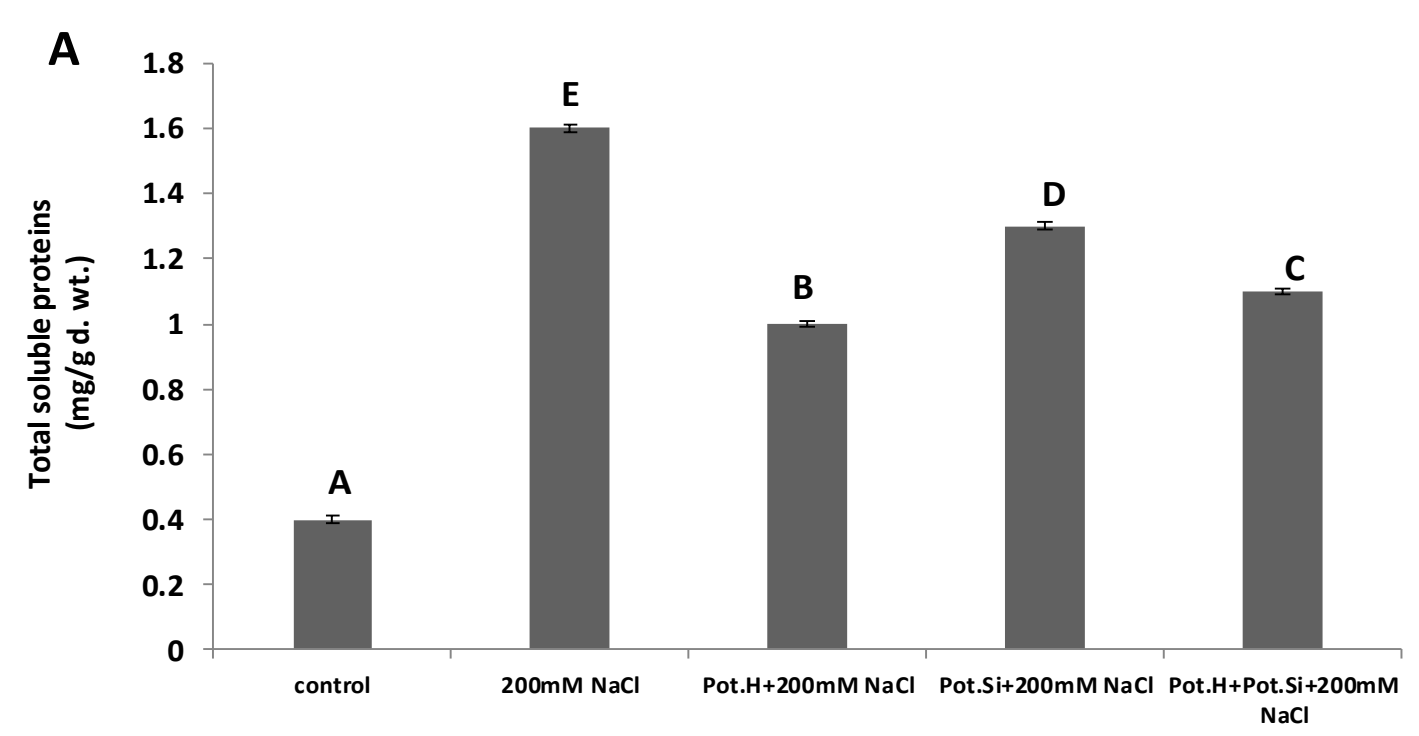

B

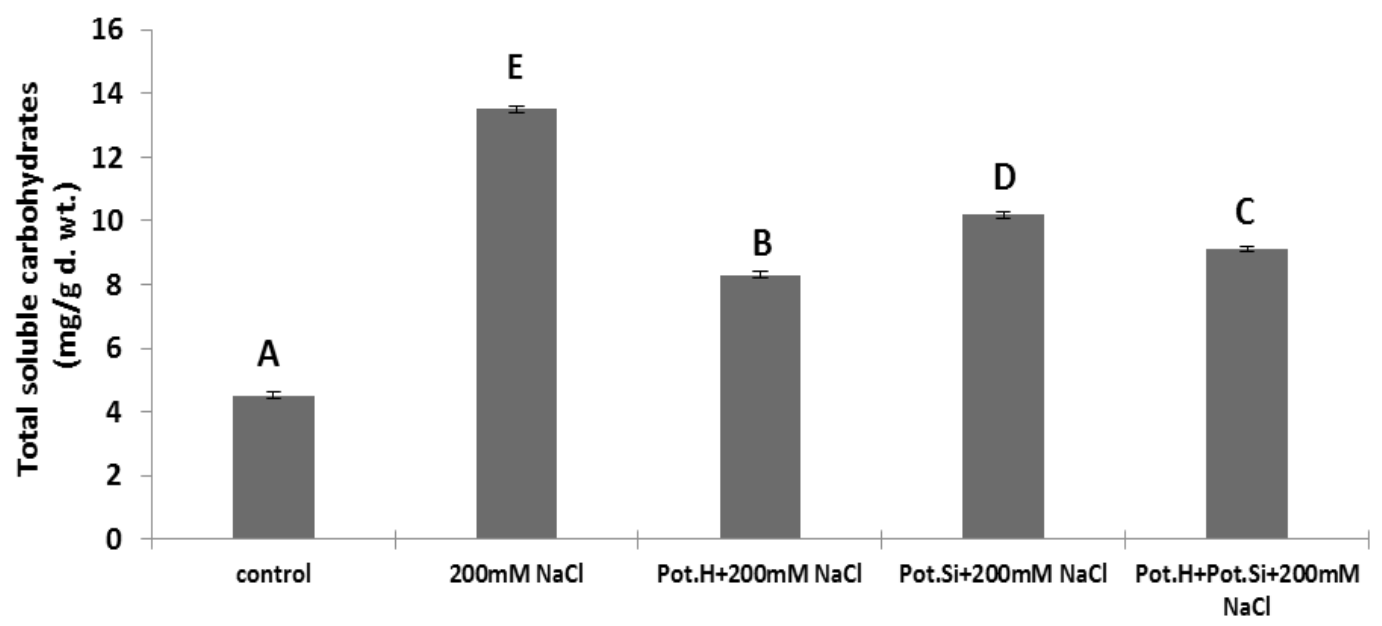

Fig.3. Effect of different concentrations of $\mathrm{NaCl}(0-200 \mathrm{mM})$ on total soluble proteins (A) and carbohydrates (B) of 30-day-old Triticum aestivum L. (cv.Gemeza.9) seedlings grown in clay sandy soil (2:1w/w), in response to soil irrigation at $(\mathbf{8 0} \%$ field capacity) followed by soil supplementation with potassium humate (Pot.H) $(0.2 \mathrm{~g} / \mathrm{pot}, 1 \mathrm{~kg} / \mathrm{fad})$ and spraying using potassium silicate $\left.(\mathrm{Pot} . \mathrm{Si})(250 \mathrm{mg} / \mathrm{L} \mathrm{SiO})_{2}\right)$ as sole or combined. Values are the mean of three replicates \pm SD, Values within the same column for each factor designed by the same letter are insignificant $(p \leq 0.05)$, Values with different letters are significant $(p \leq 0.05)$ 


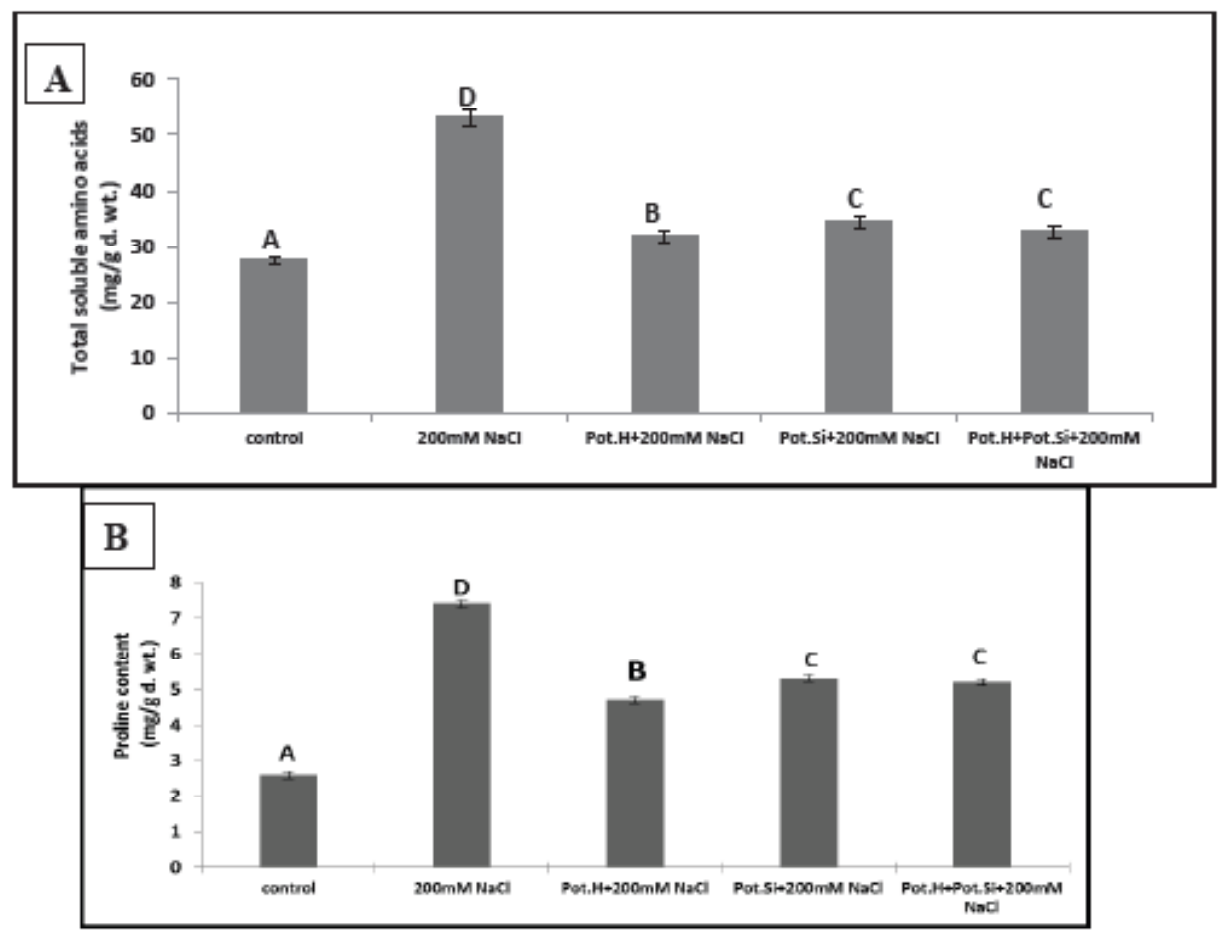

Fig.4. Effect ofdifferent concentrations of $\mathrm{NaCl}(0-200 \mathrm{mM})$ ontotal soluble amino acids (A) and proline (B) content of 30-day-old Triticum aestivum L. (cv.Gemeza.9) seedlings grown in clay sandy soil $(2: 1 \mathrm{w} / \mathrm{w})$, in response to soil irrigation at ( $80 \%$ field capacity) followed by soil supplementation with potassium humate (Pot.H) (0.2g/pot,1 kg/ fad) and spraying using potassium silicate (Pot.Si) $\left(250 \mathrm{mg} / \mathrm{L} \mathrm{SiO}_{2}\right)$ as sole or combined. Values are the mean of three replicates $\pm \mathrm{SD}$, Values within the same column for each factor designed by the same letter are insignificant $(p \leq 0.05)$, Values with different letters are significant $(p \leq 0.05)$

TABLE 4. Effect of different concentrations of $\mathrm{NaCl}(0-200 \mathrm{mM})$ on some yield parameters of 120-day-old Triticum aestivum L. (cv.Gemeza.9) grains grown in clay sandy soil $(2: 1 \mathrm{w} / \mathrm{w})$, in response to soil irrigation at $(80 \%$ field capacity) followed by soil supplementation with potassium humate (Pot.H) $(0.2 \mathrm{~g} / \mathrm{pot}, 1 \mathrm{~kg} / \mathrm{fad})$ and spraying using potassium silicate (Pot.Si) $\left(250 \mathrm{mg} / \mathrm{L} \mathrm{SiO}_{2}\right)$ as sole or combined.

\begin{tabular}{|c|c|c|c|c|c|c|c|}
\hline Treatments & $\begin{array}{l}\text { Spike length } \\
\text { (cm) }\end{array}$ & $\begin{array}{l}\text { No.of } \\
\text { spikes } \\
\text { /plant }\end{array}$ & $\begin{array}{l}\text { No.of } \\
\text { Spikelet } \\
\text { /spike }\end{array}$ & $\begin{array}{l}\text { No.of grains } \\
\quad / \text { spike }\end{array}$ & $\begin{array}{c}\text { Spike } \\
\text { weight } \\
\text { (g) }\end{array}$ & $\begin{array}{c}\text { Weight } \\
\text { of } 1000 \\
\text { grains } \\
(\mathrm{g})\end{array}$ & $\begin{array}{l}\text { Percentage } \\
\text { of maturity }\end{array}$ \\
\hline Control & $9.20 \pm 0.03^{\mathrm{d}}$ & $4.0 \pm 0.3^{\mathrm{d}}$ & $40 . \pm 1.5^{\mathrm{c}}$ & $37.33 \pm 1.5^{\mathrm{e}}$ & $1.9 \pm 0.1^{\mathrm{c}}$ & $28.4 \pm 1^{\mathrm{c}}$ & $93.3 \pm 1.5^{\text {ef }}$ \\
\hline $\begin{array}{l}200 \mathrm{mM} \\
\mathrm{NaCl}\end{array}$ & $7.40 \pm 0.01^{\mathrm{a}}$ & $1.0 \pm 0.3^{\mathrm{a}}$ & $29 \pm 1.2^{\mathrm{a}}$ & $12.00 \pm 0.6^{\mathrm{a}}$ & $0.7 \pm 0.1^{\mathrm{a}}$ & $10.1 \pm 1^{\mathrm{a}}$ & $41.3 \pm 2.5^{\mathrm{a}}$ \\
\hline $\begin{array}{l}\text { Pot.H } \\
(0.2 \mathrm{~g} / \text { pot, } 1 \mathrm{~kg} / \mathrm{fad})\end{array}$ & $11.4 \pm 0.03^{\mathrm{f}}$ & $6.0 \pm 0.3^{\mathrm{f}}$ & $50 \pm 1.2^{\mathrm{e}}$ & $48.00 \pm 1.2^{\mathrm{g}}$ & $2.8 \pm 0.1^{\mathrm{d}}$ & $46.9 \pm 1^{\mathrm{d}}$ & $96.0 \pm 1.2^{\mathrm{g}}$ \\
\hline $\begin{array}{l}\text { Pot.H+200 mM } \\
\mathrm{NaCl}\end{array}$ & $9.10 \pm 0.03^{\mathrm{d}}$ & $3.7 \pm 0.3^{\mathrm{c}}$ & $36 \pm 1.1^{\mathrm{d}}$ & $29.00 \pm 0.6^{\mathrm{d}}$ & $1.3 \pm 0.1^{\mathrm{bc}}$ & $25.8 \pm 1^{\mathrm{bc}}$ & $80.0 \pm 0.3^{\mathrm{d}}$ \\
\hline $\begin{array}{l}\text { Pot.Si } \\
\left(250 \mathrm{mg} / \mathrm{L} \mathrm{SiO}_{2}\right)\end{array}$ & $10.8 \pm 0.04^{e}$ & $4.3 \pm 0.3^{\mathrm{d}}$ & $42 \pm 1.2^{\mathrm{b}}$ & $40.00 \pm 1.2^{\mathrm{f}}$ & $2.1 \pm 0.1^{\mathrm{d}}$ & $32.4 \pm 1^{\mathrm{d}}$ & $95.2 \pm 1.2^{\mathrm{e}}$ \\
\hline $\begin{array}{l}\text { Pot.Si+200 mM } \\
\mathrm{NaCl}\end{array}$ & $8.12 \pm 0.03^{b}$ & $3.0 \pm 0.3^{\mathrm{b}}$ & $32 \pm 1.4^{\mathrm{ab}}$ & $22.00 \pm 0.5^{\mathrm{b}}$ & $1.1 \pm 0.1^{\mathrm{ab}}$ & $22.2 \pm 1^{\mathrm{b}}$ & $68.7 \pm 0.5^{\mathrm{b}}$ \\
\hline Pot.H +Pot.Si & $11.05 \pm 0.03^{\mathrm{e}}$ & $5.2 \pm 0.3^{\mathrm{e}}$ & $44 \pm 1.2^{\mathrm{d}}$ & $42.00 \pm 1.2^{\mathrm{f}}$ & $2.4 \pm 0.1^{\mathrm{d}}$ & $33.7 \pm 1^{\mathrm{d}}$ & $95.4 \pm 1.2^{\mathrm{ef}}$ \\
\hline $\begin{array}{l}\text { Pot.H+Pot.Si+200 } \\
\mathrm{mM} \mathrm{NaCl}\end{array}$ & $8.45 \pm 0.03^{\mathrm{c}}$ & $3.2 \pm 0.3^{\mathrm{b}}$ & $33 \pm 1.2^{\mathrm{ab}}$ & $25.00 \pm 0.6^{\mathrm{c}}$ & $1.2 \pm 0.1^{\mathrm{abc}}$ & $24.8 \pm 1^{\mathrm{bc}}$ & $75.5 \pm 0.5^{\mathrm{c}}$ \\
\hline $\mathrm{R}^{2}$ & $97.81 \%$ & $96.52 \%$ & $96.32 \%$ & $99.52 \%$ & $96.57 \%$ & $98.24 \%$ & $99.54 \%$ \\
\hline P-value & & & & $0.0001 * * *$ & & & \\
\hline
\end{tabular}

Values are the mean of three replicates $\pm \mathrm{SD}$, Values within the same column for each factor designed by the same letter are insignificant $(\mathrm{p} \leq 0.05)$, Values with different letters are significant $(\mathrm{p} \leq 0.05)$. 
Total soluble proteins and carbohydrates of the produced grains

The results in Fig. 5 show that high salinity level at $200 \mathrm{mM}$ caused a significant decrease in the total soluble protein and carbohydrates of produced grains and this decrease was represented by $216 \%$ and $183 \%$, respectively compared with control. Accordingly, application of potassium humate and potassium silicate single or combined were significant increased the content of total soluble protein and carbohydrates in the yielded grains. Results indicated that addition of potassium humate as sole increased the content of total soluble proteins and carbohydrates by $100 \%$ and $188 \%$, respectively while potassium silicate and the combined treatments increased them by $40 \%$ and $118 \%$, respectively compared with control.
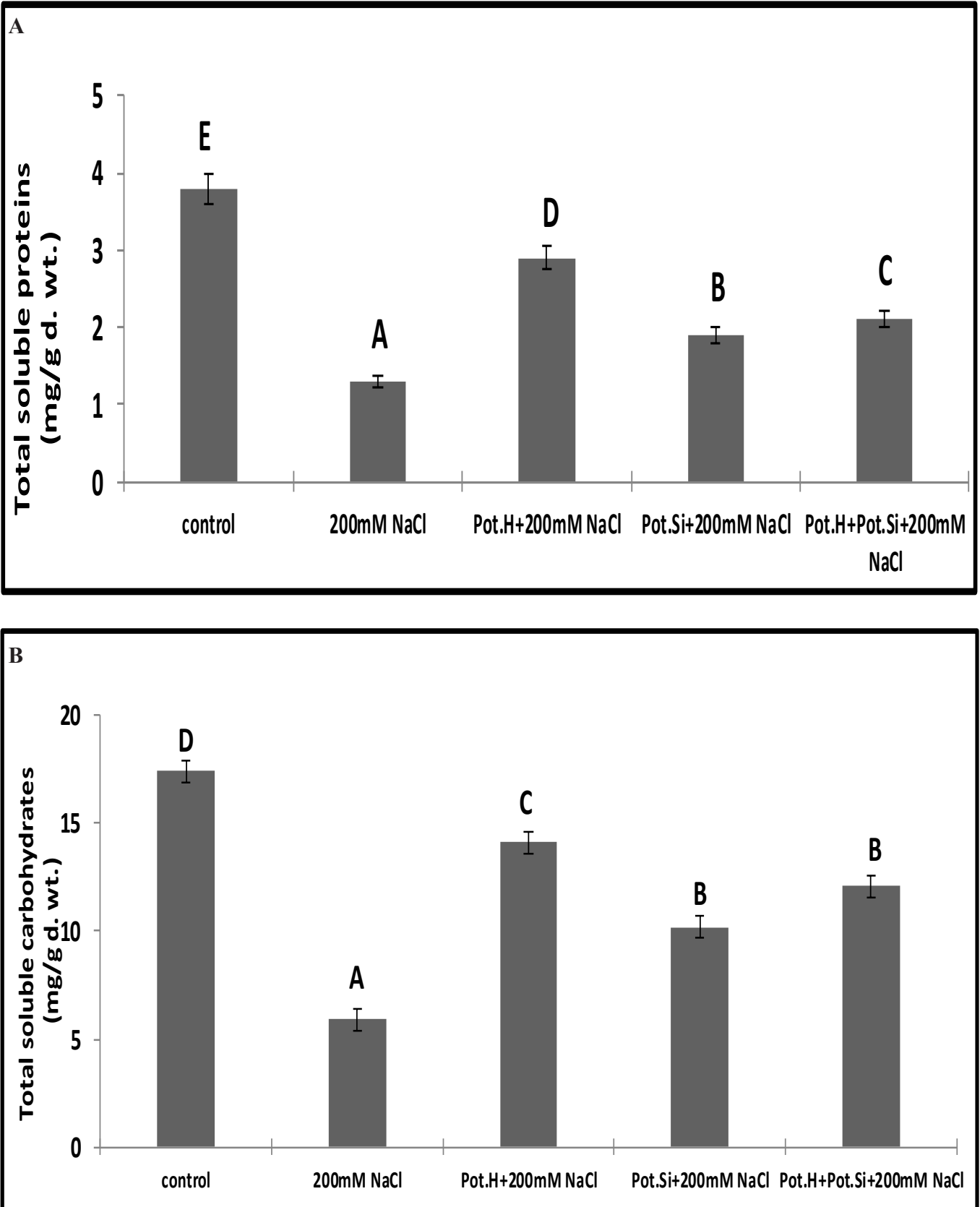

Fig.5. Effect of different concentrations of $\mathrm{NaCl}(0-200 \mathrm{mM})$ on total soluble proteins $(\mathrm{A})$ and carbohydrates $(\mathrm{B})$ of 120-day-old Triticum aestivum L. (cv.Gemeza.9) grains grown in clay sandy soil $(2: 1 \mathrm{w} / \mathrm{w})$, in response to soil irrigation at $(80 \%$ field capacity) followed by soil supplementation by $(0.2 \mathrm{~g} / \mathrm{pot}, 1 \mathrm{~kg} / \mathrm{fad})$ potassium humate and spraying with $\left.(250 \mathrm{mg} / \mathrm{L} \mathrm{sio})_{2}\right)$ potassium silicate as sole or combined. Values are the mean of three replicates $\pm \mathrm{SD}$, Values within the same column for each factor designed by the same letter are insignificant $(p \leq 0.05)$, Values with different letters are significant $(p \leq 0.05)$. 


\section{Discussion}

Germination and plant growth

Seed germination is the initial step in plant life where, it has an influential role in yield (Sanchez et al., 2014). Wheat seedlings are more sensitive to salinity during germination than during emergence and early seedlings growth (Aflaki et al., 2017). In the present study, Gemeza.9 couldn't tolerate high $\mathrm{NaCl}$ level $(200 \mathrm{mM})$ and its germination percentage was reduced (Table 1 and 2) also, all growth parameters were decreased in response to salinity stress (Table 3). Salinity delays or prevents seed germination and seedling establishment due to its effect on water absorption by reducing water potential (osmotic stress) that reduce water uptake by plants (Jeannette et al., 2002). High accumulation of salts in soils and intercellular spaces of the cells induces damage of the embryo (Rahman et al., 2008). Accordingly, the reduction of growth may be attributed to osmotic imbalance and ion toxicity under continuous exposure of the plant to saline conditions leading to changing in their morphology and anatomy (Singh, 2016). Similar observations were reported by Aflaki et al. (2017) in wheat.

As shown in our results, potassium humate had a marked effect against salinity stress. it increased the germination percentage (Table 2) and all measured growth parameters (Table 3). This ameliorative effect may be attributed to the entrance of humic substances into the cells carrying both micronutrients and water. They also increase water permeability of plant membranes and water holding capacity (Kumar \& Singh, 2017). Many observations were documented about the high efficiency of humic substances and their effects on the plant growth (Chen \& Aviad, 1990; Nardi et al., 2007; Cesco et al., 2002 and Rady, 2012). Yang et al. (2004) reported that humate substances can indirectly and directly affect the physiological processes of plant growth by providing minerals uptake and biochemical substances, and carry trace elements and growth regulators for enhancing the plant's growth.

The effective role of potassium silicate in increasing the growth parameters was attributed to increasing water contents in wheat (Ali et al., 2012) and photosynthetic efficiency which leads to increasing the plant's growth (Pati et al., 2017). It was hypothesized that the silicon decreases of uptake $\mathrm{Na}^{+}$by plants under salt stress and the increase of $\mathrm{K}^{+} / \mathrm{Na}^{+}$ratio also prevented $\mathrm{Na}^{+}$ translocation in leaves and/or specific deposition in roots (Guntzer et al., 2011 and Abbas et al., 2015).Similar observation was reported by Ibrahim et al. (2016) in wheat.

\section{Photosynthetic parameters}

Photosynthetic process is very sensitive under stress conditions including salinity. According to data shown in Fig.1 which indicated that salinity stress reduced the photosynthetic efficiency (Fig.1A) and photosynthetic pigments (Chl.a and Chl.b) (Fig, 1B) could be attributed to stomatal closure (Bacelar et al., 2006) and/or downregulation of $\mathrm{CO}_{2}$ fixation. In addition increasing $\mathrm{H}_{2} \mathrm{O}_{2}$ induced by oxidative stress increase the photo-oxidation of photosystem antennae under salinity stress (Yamazaki et al., 2003 and Kafi, 2009). The reduction of Chl.a and Chl.b may be due to an increase of chlorophyllase enzyme which converts chlorophyll into chlorophyllide and phytol (Morita et al., 2009 and Lin et al., 2016) and/or damaging of photosynthetic apparatus through block of pigment-protein complexes (proteins of PSII) which synthesized in the chloroplasts (Nishiyama et al., 2011). More or less similar results were reported by Hidri et al. (2016). The results showed also that carotenoids were highly increased under salinity stress. This may be due to adaptation of the plant with high salt stress through stimulation of antioxidant defense systems (Liu et al., 2009 and He et al., 2009). Carotenoids are considered as one of the most important non-enzymatic antioxidant which induced decrease the accumulation of ROS under salt stress (Mittler et al., 2004) also, they induce abscisic acid hormone that promotes stomatal closure when exposed to stress (Leung \& Giraudat, 1998). More or less similar data were reported by Liu et al. (2009).

The present results revealed high efficiency of potassium humate to ameliorate the deleterious effect of salinity stress by increasing chlorophyll A, chlorophyll B and carotenoids contents (Fig.1). This amelioration effect may be attributed to high efficiency of humic acid in increasing chlorophyll-A and chlorophyll-B content, stimulating the enzymes related to photosynthetic process, reducing electrolyte leakage and increasing the uptake of magnesium and iron which are required for chlorophyll biosynthesis (El-Ghamry et al., 2009 and Arafa 
et al., 2011). Applying silicon to wheat improved photosynthetic activity. Tuna et al. (2008) found that silicon increases chlorophyll pigments under normal and salinity stress conditions. Applying silicon to saline soils resulted in reducing the amount of $\mathrm{Na}^{+}$taken up by plants leading to maintaining photosynthesis process (Wang \& Han, 2007). Similarly, Rios et al. (2014) found an increase in chlorophyll pigments in wheat leaves when silicon was applied. In soybean, silicon increased of photosynthetic enzymes leading to a high increase in photosynthetic pigments (Shen et al., 2010).

\section{Antioxidant defense system}

Data represented in Fig. 2 indicated that salinity stress caused a significant increase of peroxidase and catalase activities as well as malondialdehyde (MDA) and ascorbic acid contents. This increase may be due to the synthesis of reactive oxygen species (ROS) (Baxter et al., 2014 and Dietz et al., 2016). Antioxidant enzymes such as peroxidase and catalase are scavenging enzymes which regulate hydrogen peroxide $\left(\mathrm{H}_{2} \mathrm{O}_{2}\right)$ content, thus inhibiting the production of $\mathrm{OH}^{-}$radicals which produced from photorespiration and $\beta$-oxidation of fatty acids in organelles during metabolic processes (Rout \& Shaw, 2001 and Bhutta, 2011). Damaging of membranes fatty acids could produce small hydrocarbon fragments including MDA which is an important sign of membrane system injury (Masood et al., 2006 and Moussa, 2008). Ascorbic acid is an important water-soluble antioxidant and cell moderator in physiological processes including photoprotection (Wolucka, 2005 and Khan \& Ashraf, 2008) where, it can rapidly react with radical intermediates of an autoxidation chain and stop it (Khan, 2006). Latef (2014) reported that salt stress induced oxidative stress by increasing malondialdehyde (MDA) content and activity of peroxidase. Vaidyanathan et al. (2003) investigated the effect of different levels of salinity (100-300 mM) on rice (Oryza sativa L.) cultivar and they showed higher activities of the ROS scavenging enzymes.

Our results show clearly that potassium humate caused a significant inhibition of the activity of catalase and peroxidase and reduced MDA and ascorbic acid contents in saltstressed plants. This amelioration effect could be attributed to protection of cell membranes from lipid peroxidation through increasing of metallic ions uptake and cell which is related to the activity of both hydrophilic and hydrophobic sites on the surface of humic substances (Haghighi et al., 2010). Humic acids were the most effective fraction during the production of $\mathrm{O}_{2}^{-}$through regulation of the xanthine /xanthine oxidase system which is the important key role in increasing antioxidant defense compounds (Vaughan \& Ord, 1982; Cheng et al., 1995; Moussa, 2008 and Berbaraa \& García, 2014).

Application of silicon decreased activities of antioxidant enzymes under salinity stress; this is associated with decreasing of electrolyte leakage, ROS synthesis and $\mathrm{H}_{2} \mathrm{O}_{2}$ contents (Siddiqui et al., 2014 and Shahid et al., 2015). More or fewer data were reported by Abbas et al. (2015) that foliar application of silicon $\left(150 \mathrm{mgL}^{-1}\right)$, decreased lipid peroxidation and increased antioxidant enzymes activities in both leaves and root of okra under salt stress.Similar studies showed that siliconmediated enhancement in antioxidant enzyme activities and decreased in oxidative stress in saltstressed tomato plants grown in sand culture ( $\mathrm{Li}$ et al., 2015).

Total soluble proteins, carbohydrates, amino acids and proline content

Figure 3 and Fig.4 indicated that salinity stress caused highly significant increases in all the assessed organic compounds (total soluble sugars proteins, amino acids and proline content). This increase may be due to osmotic adjustment. These compatible solutes enhance the tolerance of plants and increasing their adaptation to severe stresses (Fahad et al., 2015). Proline has also been considered as a carbon and nitrogen source for rapid recovery from stress, a stabilizer for membranes and some macromolecules, a free radical scavenger (Jain et al., 2002) and a protective agent for cytosolic enzymes and cellular organelles (Yazici et al., 2007).

Potassium humate increased biosynthesis of organic compounds and this might be directly related to their role in increasing plant tolerance against abiotic stress and the activity of immune plant system (Hanafy et al., 2010). This is attributed to accelerating of plant energy metabolism through enhancing photosynthesis process and formation of starch (Mady, 2009). Humate substances increase uptake of oxygen for synthesis of protein enzymes which activate the formation of both carrier and structural proteins (Pettit \& Robert, 2004). This is in agreement 
with the findings of Hanafy et al. (2010) and ElBassiony et al. (2010). Moreover, Aydin et al. (2012) studied the effect of humic acid in the alleviation of salinity stress in Phaseolus vulgaris L. and concluded that humic acid had significantly recovered the harmful effect of salinity and decreased amount of all organic compounds contents in bean plants.

Potassium silicate application caused an increase in biosynthesis of all determined organic osmolytes. Abbas et al. (2015) reported that foliar application of silicon increased proline, glycinebetaine, and total free amino acids in both shoots and roots of salt-stressed okra plant. Reduction in proline contents with silicon application under stress has been observed in many plant species such as soybean (Lee et al., 2010), maize (Moussa, 2006). Shekari et al. (2015) observed that addition of silicon increased soluble carbohydrates content in plants grown under salt stress where, they act as a protective osmolyte; also they reported that application of silicon under saline condition could be a better strategy for maintaining the crop productivity.

\section{Yield parameters}

Data in Table 4 indicated that salinity stress caused inhibition in all measured yield parameters. This inhibition may be due to formation of spikes during emergence and their abortion at later stages (Nicolas et al., 1994 and Chaabane et al., 2011). Potassium humate and potassium silicate increased the productivity and maturity of produced grains where, all measured yield growth parameters expressed highly significant increase as a result of their pronounced roles in enhancing physiological processes and growth of seedling where, these effects reflected on growth of yielded grains in stressed plant. Hemida et al. (2017) reported that potassium humate significantly improved the physical and chemical properties of soil. These effects were positively reflected on plant growth and productivity in Phaseolus vulgaris under salinity stress.

Hellal et al. (2012) and Kardoni et al. (2013) reported that silicon application increased pod yield, seed number per plant, chlorophyll contents, and yield of faba bean (Vicia faba L.) under salt stress. Similarly, application of potassium silicate increased plant weight, ear length, seed yield, and chlorophyll content in wheat under salt stress (Bybordi, 2014).
Total soluble proteins and carbohydrates of produced grains

Yield is a measure of the activity of processes contributing to deposition of starch in the grains, and protein percentage (Jenner, 1991). Data represented in Fig. 5 indicate that salinity stress caused a significant reduction in total soluble proteins and carbohydrates of grains where, salinity may cause nutrient deficiencies or imbalances, due to the competition of $\mathrm{Na}^{+}$and $\mathrm{Cl}^{-}$with nutrients such as $\mathrm{K}^{+}, \mathrm{N}$, and $\mathrm{Ca}^{2+}(\mathrm{Hu} \&$ Schmidhalter, 2005). Nitrogen-deficiency during early reproductive development severely limits crop yield (Dolferus et al., 2011). Moderate reduction in nitrogen, reduces sink protein capacity (Hirel et al., 2007 and Yang \& Zhang, 2010).

Accordingly, potassium humate and potassium silicate had pronounced roles in enhancing physiological processes and growth of stressed seedlings where, these effects reflected on growth of yielded grains. Furthermore, potassium humate resulted in a remarkable increase in total soluble proteins and carbohydrates contents of grains and this may be due to increase of photosynthesis process which leads to formation of starch and/ or increase $\mathrm{N}^{+}, \mathrm{P}^{+}$and $\mathrm{K}^{+}$uptake and increase the ratios of $\mathrm{K}^{+} / \mathrm{Na}^{+}$and $\mathrm{Ca}^{+2} / \mathrm{Na}^{+}$which are necessary for plant growth (EL-Bassiony et al., 2010 and El-Hefny, 2010). On other hands, potassium silicate enhances the increase of grain's proteins and carbohydrates as a result of increasing the photosynthetic process and/or increasing the uptake and translocation of mineral elements in plants $\mathrm{N}^{+}, \mathrm{P}^{+}$and $\mathrm{K}^{+}$and $\mathrm{Ca}^{+2}$, which they are important in increasing biosynthesis of proteins and carbohydrates (Hellal et al., 2012).

\section{Conclusion}

Salinity is one of the major limitations to wheat production worldwide. The present study demonstrates the effect of salinity stress on wheat at all growth stages. There are several strategies to increase wheat production in the salt-affected areas. One of the most important strategies for amending soil is supplemental it by organic materials that play a key role in the enhancement of plant growth and maintaining the crop yields. It can be concluded that, applying potassium humate as sole had a pronounced role in regulating the biochemical and physiological processes of wheat plant. Enhancement of wheat growth and productivity could be achieved by potassium humate treatment through inhibition 
of antioxidant enzymes activity and reducing oxidation status under salinity stress. On other hands, foliar application of potassium silicate to wheat plant may help to overcome the deleterious effects of salinity and improve the adaptation capability of wheat to the saline environment where potassium silicate showed more beneficial effects on its growth and yield production. Finally, it was concluded that, applying potassium humate as an organic fertilizer as sole was more effective than potassium silicate or their combination on ameliorating the toxic effect of salinity stress.

\section{References}

Abbas, T., Balal, R.M., Shahid, M.A., Pervez, M.A., Ayyub, C.M., Aqueel, M.A. and Javaid, M.M. (2015) Silicon-induced alleviation of $\mathrm{NaCl}$ toxicity in okra (Abelmoschus esculentus) is associated with enhanced photosynthesis, osmoprotectants and antioxidant metabolism. Acta. Physiol. Plant. 37, 1-15.

Aflaki, F., Sedghi, M., Pazuki, A. and Pessarakli, M. (2017) Investigation of seed germination indices for early selection of salinity tolerant genotypes: A case study in wheat. Emir. J. Food Agr. 29 (3), 222.

Ahmad, A., Afzal, M., Ahmad, A.U.H. and Tahir, M. (2013) Effect of foliar application of silicon on yield and quality of rice (Oryza sativa L). Cer. Agron. Moldova. 46 (3), 21-28.

Ali, A., Shahzad, M.A., Hussain, S., Iqbal, J., Haji, M.A. and Sarwar, M. (2012) Salt stress alleviation in field crops through nutrition supplementation of silicon. Pak. J. Nutr. 8, 637-655.

Arafa, A.A., Farouk, S. and Hager, S.M. (2011) Effect of potassium fertilizers, biostimulant and effective microorganisms as well as their interactions on potato growth, photosynthetic pigments and stem anatomy. J. Plant Prod. 2 (8), 1017-1035.

Arnon, D.I. (1949) Copper enzymes in isolated chloroplasts. Polyphenoloxidase in Beta vulgaris. Plant Physiol. 24, 1-15.

Aydin, A., Kant, C. and Turan, M. (2012) Humic acid application alleviate salinity stress of bean (Phaseolus vulgaris L.) plants decreasing membrane leakage. Afr. J. Agric. Res. 7 (7), 1073-1086.

Bacelar, E.A., Santos, D.L., Moutinho-Pereira, J.M., Gonc-alves, B.C., Ferreira, H.F. and Correia, C.M. (2006) Immediate responses and adaptative strategies of three olive cultivars under contrasting water availability regimes: Changes on structure and chemical composition of foliage and oxidative damage. Plant.Sci. 170, 596-605.
Bates, L.S., Waldren, R.P. and Teare, I.D. (1973) Rapid determination of free proline for water-stress studies. Plant and Soil, 39, 205-207.

Baxter, A., Mittler, R. and Suzuki, N. (2014) ROS as key players in plant stress signaling. J. Exp. Bot. 65,12291240.

Beauchamp, C. and Fridovich, I. (1971) Superoxide dismutase, improved assays and an assay applicable to acrylamide gels. Anal. Biochem. 44, 276-287.

Berbara, R.L. and García, A.C. (2014) Humic substances and plant defense metabolism: In "Physiological Mechanisms and Adaptation Strategies in Plants Under Changing Environment". pp. 297-319. Springer New York., .

Bradford, M.M. (1976) A rapid and sensitive method for the quantification of microgram quantities of protein utilizing the principle of protein dye binding. Anal. Biochem. 72, 248-254.

Bhutta, W. M. (2011) Antioxidant activity of enzymatic system of two different wheat (Triticum aestivum L.) cultivars growing under salt stress. Plant Soil Environ. 57 (3), 101-107.

Bybordi, A. (2014) Interactive effects of silicon and potassium nitrate in improving salt tolerance of wheat. Int. J. Agric. 13, 1889-1899.

Canellas, L.P., Olivares, F.L., Aguiar, N.O., Jones, D.L., Nebbioso, A., Mazzei, P. and Piccolo, A. (2015) Humic and fulvic acids as biostimulants in horticulture. Sci. Hort. 196, 15-27.

Cesco, S., Nikolic, M., Römheld, V., Varanini, Z. and Pinton, R. (2002) Uptake of 59Fe from soluble Fehumate complexes by cucumber and barley plants. Plant Soil, 241, 121-128.

Chaabane, R., Bchini, H., Ouji, H., Salah, H.B., Khamassi, K., Khoufi, S. and Naceur, M.B. (2011) Behaviour of Tunisian durum wheat (Triticum turgidum $\mathrm{L}$.) varieties under saline stress. P. J. Nutr. 10 (6), 539-542.

Chen, Y. and Aviad, T. (1990) Effects of humic substances on plant growth. In: "Humic Substances in Soil and Crop Science", MacCarthy, P., Clapp, C.E., Malcolm, R.L., and Bloom, P.R., (Ed.), pp. 161-186. Madison: American Society of Agronomy and Soil Science Society of America.

Cheng, F.J., Yang, D.Q. and Wu, Q.S. (1995) Physiological effects of humic acid on drought resistance of wheat, $J$. Appl. Ecol. 6, 363-367.

Das, N.R. (2008) "Wheat Crop Management". Scientific Publication, Jodhpur. 
Dietz, K.J., Turkan, I. and Krieger-Liszkay, A. (2016) Redox-and reactive oxygen species-dependent signaling into and out of the photosynthesizing chloroplast. Plant Physiol. 171 (3), 1541-1550.

Dolferus, R., Ji, X. and Richards, R.A. (2011) Abiotic stress and control of grain number incereals. Plant Sci. 181, 331-341.

Dubois, M., Gilles, K., Hamilton, J., Rebers, P. and Smith, F. (1956) Colorimetric method for determination of sugars and related substances. Anal. Chim. 28, 350-356.

El-Bassiony, A.M., Fawzy, Z.F., Abd El-Baky, M.M. H. and Mahmoud, A.R. (2010) Response of snap bean plants to mineral fertilizers and humic acid application. Res. J. Agric. Biologic. Sci. 6 (2), 169-175.

El-Ghamry, A.M., Abd El-Hai, K.M. and Ghoneem, K.M. (2009) Amino and humic acids promote growth, yield and disease resistance of faba bean cultivated in clayey soil. Aust. J. Basic Appl. Sci. 3 (2), 731-739.

El-Hefny, E.M. (2010) Effect of saline irrigation water and humic acid application on growth and productivity of two cultivars of cowpea (Vigna unguiculata L. Walp.). Aust. J. Basic Appl. Sci. 4, 6154-6168.

Fahad, S., Hussain, S., Matloob, A., Khan, F.A., Khaliq, A., Saud, S. and Faiq, M. (2015) Phytohormones and plant responses to salinity stress. Plant Growth Reg. 75 (2), 391-404.

FAO (Food and Agriculture Organization). (2010) FAOSTAT database. [Accessed on 10 December 2010]. Available online: http://www.faostat.fao.org/.

FAO (Food and Agriculture Organization). (2016) FAO GIEWS Country Brief on Egypt. 28-November-2016. www.fao.org/giews/countrybrief/country. jsp? code $=$ EGY

Guntzer, F., Keller, C. and Meunier, J.D. (2011) Benefits of plant silicon for crops: a review. Agron. Sustain. Dev. 32, 201-213.

Haghighi, S., SakiNejad, T. and Lack, S. (2011) Effect of biological fertilizer of humic acid on metabolic process of biological nitrogen fixation, Life Sci. J. 8, 43-48.

Hanafy, A.A. H., Nesiem, M.R., Hewedy, A.M. and Sallam, H. (2010) Effect of some simulative compounds on growth, yield and chemical composition of snap bean plants grown under calcareous soil conditions. J. Amer. Sci. 6 (10), 552-569.
Hasanuzzaman, M., Alam, M.M., Rahman , A., Nahar, K. and Fujita, M. (2014) Exogenous proline and glycinebetaine mediated upregulation of antioxidant defense and glyoxalase systems provides better protection against salt-induced oxidative stress in two rice (Oryza sativa L.) varieties. Biol. Med. Re. Int., 17.http://dx.doi.org/10.1155/2014/757219.

He, S., Han, Y., Wang, Y., Zhai, H. and Liu, Q. (2009) In vitro selection and identification of sweet potato (Ipomoea batatas L.) plants tolerant to $\mathrm{NaCl}$. Plant Cell Tissue Organ Cult. 96, 69-74.

Heath, R.L. and Packer, L. (1968) Photoperoxidation in isolated chloroplasts. I.Kinetics and stoichiometry of fatty acid peroxidation. Arch. Biochem. Biophys.125, 189-198.

Hellal, F.A., Abdelhameid, M., Abo-Basha, D.M. and Zewainy, R.M. (2012) Alleviation of the adverse effects of soil salinity stress by foliar application of silicon on faba bean (Vicia faba L.). J. Appl. Sci. Res. 8, 4428-4433.

Hemida, K.A., Eloufey, A.Z., Seif El-Yazal, M.A. and Rady, M.M. (2017) Integrated effect of potassium humate and $\alpha$-tocopherol applications on soil characteristics and performance of Phaseolus vulgaris plants grown on a saline soil. Arch. Argon. Soil. Sci. 1-16.

Hidri, R., Barea, J.M., Mahmoud, O.M.B., Abdelly, C. and Azcón, R. (2016) Impact of microbial inoculation on biomass accumulation by Sulla carnosa provenances, and in regulating nutrition, physiological and antioxidant activities of this species under non-saline and saline conditions. $J$. Plant Physiol. 201, 28-41.

Hirel, B., Le Gouis, J., Ney, B. and Gallais, A. (2007) The challenge of improving nitrogenuse efficiency in crop plants: towards a more central role for genetic variability and quantitative genetics within integrated approaches. J. Exp. Bot. 58, 2369-2387.

Hu, Y. and Schmidhalter, U. (2005) Drought and salinity: a comparison of their effects on mineral nutrition of plants. J. Plant Nutr. Soil. Sci., 168 (4), 541-549.

Ibrahim, M.A., Merwad, A.M., Elnaka, E.A., Burras, C.L., and Follett, L. (2016) Application of silicon ameliorated salinity stress and improved wheat yield. J. Soil. Sci. Environ. Mang.7 (7), 81-91.

Jain, M., Mathur, G., Koul, S. and Sarin, N. B. (2002) Ameliorative effects of proline on salt stressinduced lipid peroxidation in cell lines of groundnut (Arachis hypogea L.). Plant Cell Rep. 20, 463-468.

Jeannette, S., Craig, R. and Lynch, J.P. (2002) Salinity 
tolerance of Phaseolus species during germination and early seedling growth. Crop. Sci. 42, 1584-1594.

Jenner, C.F., Ugalde, T.D. and Aspinall, D. (1991) The physiology of starch and protein deposition in the endosperm of wheat. Funct. Plant Biol., 18 (3), 211-226.

Kafi, M. (2009) The effects of salinity and light on photosynthesis, respiration and chlorophyll fluorescence in salt-tolerant and salt-sensitive wheat (Triticum aestivum L.) cultivars. J. Agr. Sci. Tech. 11, 535-547.

Kandil, A.A., Sharief, A.E.M., Seadh, S.E. and Altai, D.S. (2016) Role of humic acid and amino acids in limiting loss of nitrogen fertilizer and increasing productivity of some wheat cultivars grown under newly reclaimed sandy soil. Int. J. Adv. Res. Biol. Sci., 3 (4), 123-136.

Kardoni, F., Mosavi, S.J.S., Parande, S. and Torbaghan, M.E. (2013) Effect of salinity stress and silicon application on yield and component yield of faba bean (Vicia faba L.). Int. J. Agric. Crop. Sci. 6, 814-818.

Kato, M. and Shimizu, S. (1987) Chlorophyll metabolism in higher plants. VII. Chlorophyll degradation in senescing tobacco leaves; phenolicdependent peroxidative degradation. Cand. J. Bot.65 (4), 729-735.

Khan, M. (2006) Effect of sea salt and L-ascorbic acid on the seed germination of halophytes. $J$. Environ.67, 535-540.

Khan, A. and Ashraf, M. (2008) Exogenously applied ascorbic acid alleviates salt-induced oxidative stress in wheat. Environ. Exp. Bot. 63 (1), 224-231.

Kumar, D. and Singh, A.P. (2017) Efficacy of potassium humate and chemical fertilizers on yield and nutrient availability patterns in soil at different growth stages of rice. Commun. Soil. Sci. Plant Anal. 48 (3), 245-261.

Latef, A.A.H.A. and Chaoxing, H. (2014) Does inoculation with Glomus mosseae improve salt tolerance in pepper plants?. J. Plant Growth Reg. 33 (3), 644-653.

Lee, S.K., Sohn, E.Y., Hamayun, M., Yoon, J.Y. and Lee, I.J. (2010) Effect of silicon on growth and salinity stress of soybean plant grown under hydroponic system. Agrofor.Syst. 80, 333-340.

Lee, Y.P. and Takahashi, T. (1966) An improved colorimetric determination of amino acids with the use of ninhydrin. Analytical Biochemistery, 14, 71-77.

Leung, J. and Giraudat, J. (1998) Abscisic acid signal transduction. Annu. Rev. Plant Physiol. Plant Mol. Biol. 49, 199-222.

Li, H., Zhu, Y., Hu, Y., Han, W. and Gong, H. (2015) Beneficial effects of silicon in alleviating salinity stress of tomato seedlings grown under sand culture. Acta. Physiol. Plant. 37, 1-9.

Lin, Y.P., Wu, M.C. and Charng, Y.Y. (2016) Identification of a chlorophyll dephytylase involved in chlorophyll turnover in Arabidopsis. The Plant Cell, 28 (12), 2974-2990.

Liu, Y., Zhao, Z., Si, J., Di, C., Han, J. and An, L. (2009) Brassinosteroids alleviate chilling-induced oxidative damage by enhancing antioxidant defense system in suspension cultured cells of Chorispora bungeana. Plant Growth Regulation, 59(3), 207-214.

Mady, M.A. (2009) Effect of foliar application with yeast extract and zinc on fruit setting of Faba bean (Vicia faba L.). J. Biolo. Chem. Environ. Sci. 4 (2), 109-127.

Malav, A.K., Monpara, B.A., Gaur, A. and Bhati, S.S. (2017) Character association analysis in yield and yield components in bread wheat (Triticum aestivum L.) genotypes. J. Plant Develop. Sci. 9 (2), 77-83.

Masood, A., Ahmad, S.N., Zeeshan, M. and Abraham, G. (2006) Differential response of antioxidant enzymes to salinity stress in two varieties of Azolla (Azolla pinnata and Azolla filiculoides). Environ. Exp. Bot., 58, 216-222.

Mittler, R., Vanderauwera, S., Gollery, M. and Van Breusegem, F. (2004) Reactive oxygen gene network of plants. Trends Plant Sci. 9,490-498.

Morita, R., Sato, Y., Masuda, Y., Nishimura, M., and Kusaba, M. (2009) Defect in non-yellow coloring 3 , a/ß hydrolase-fold family protein, causes a staygreen phenotype during leaf senescence in rice. Plant J. 59, 940-952.

Moussa, H.R. (2006) Influence of exogenous application of silicon on physiological response of salt-stressed maize (Zea mays L.). Int. J. Agric. Biol. 8, 293-297.

Moussa, S.A. (2008) Oxidative stress in diabetes mellitus. Romanian J. Biophys. 18 (3), 225-236.

Nardi, S., Muscolo, A., Vaccaro, S., Baiano, S., Spaccini, R. and Piccolo, A. (2007) Relationship between molecular characteristics of soil humic fractions and glycolytic pathway and krebs cycle in maize seedlings. Soil Biol. Biochem. 39, 3138 3146 .

Nicolas, M.E., Munns, R., Samarakoon, A.B., Gifford, 
R.M. (1994) Elevated $\mathrm{CO}_{2}$ improves the growth of wheat under salinity. Aust. J. Plant Physiol. 20, 349360.

Nishiyama, Y., Allakhverdiev, S.I. and Murata, N. (2011) Protein synthesis is the primary target of reactive oxygen species in the photoinhibition of photosystem II. Physiol. Plant, 142, 35-46.

Oser, B.L. (1979) "Hawk's Physiological Chemistry."Mc Graw Hill; NY; USA, pp. 702-705.

Parker, R. and Ring, S.G. (2001) Aspects of the physical chemistry of starch. J. Cer. Sci. 34, 1-17.

Pati, S., Pal, B., Badole, S., Hazra, G.C. and Mandal, B. (2016) Effect of silicon fertilization on growth, yield, and nutrient uptake of rice. Commun. Soil. Sci. Plant Anal. 47 (3), 284-290.

Pettit, R.E. and Robert, E. (2004) Organic matter, humus, humates humic acid, fulvic acid and humin: Their importance in Soil Fertility and Plant Health, CTI Research.

Qadir, M., Quillerou, E. and Nangia, V. (2014) Economics of salt-induced land degradation and restoration. Natur. Res. For. 38, 282-295.

Rady, A.A. (2012) A novelorgano-mineral fertilizercan mitigate salinity stress effects for tomato production on reclaimed saline soil. South Afr. J. Bot. 81, 8-14.

Rahman, M., Soomro, U.A., Haq, M.Z. and Gul, S. (2008) Effects of $\mathrm{NaCl}$ salinity on wheat (Triticum aestivum L.) cultivars. World J. Agri. Sci. 4, 398403.

Rios, J.A., Ávila-Rodrigues, F., Debona, D. and Silva, L.C. (2014) Photosynthetic gas exchange in leaves of wheat plants supplied with silicon and infected with Pyricularia oryzae. Acta Physiol. Plant, 36, 371-379.

Rout, N.P. and Shaw, B.P. (2001) Salt tolerance in aquatic macrophytes: Possible involvement of the antioxidative enzymes. Plant. Sci. 160, 415-423.

Sanchez, P.L., Chen, M.K., Pessarakli, M., Hill, H.J., Gore, M.A. and Jenks, M.A. (2014) Effects of temperature and salinity on germination of non-pelleted and pelleted Guayule (Parthenium argentatum A. Gray) seeds. J. Ind. Crops Prod. 55, 90-96.

Sapre, S.S. and Vakharia, D.N. (2017) Silicon induced physiological and biochemical changes under polyethylene glycol-6000 water deficit stress in wheat seedlings. J. Environ. Biol. 38 (2), 313.

Sen, D.N., Kasera, P.K., and Mohammed, S. (2002) Biology and physiology of saline plants. "Handbook of Plant and Crop Physiology," $2^{\text {nd }}$ ed. pp.563-581. Dekker, New York.

Shahid, M.A., Balal, R.M., Pervez, M.A., Abbas, T., Aqeel, M.A., Javaid, M.M. and Garcia-sanchez, F. (2015) Foliar spray of phyto-extracts supplemented with silicon: an efficacious strategy to alleviate the salinity-induced deleterious effects in pea (Pisum sativum L.). Turk. J. Bot. 39, 408-419.

Shahryari, R., Gadimov, A., Gurbanov, E. and Valizade, M. (2009) Applications of potassium humate to wheat for organic agriculture in Iran. As. J. Food Ag-Ind. 164-168.

Shekari, F., Abbasi, A. and Mustafavi, S.H. (2015) Effect of silicon and selenium on enzymatic changes and productivity of dill in saline condition. J. Saudi Soc. Agric. Sci http://doi.org/10.1016/j. jssas.2015.11.006.

Shen, X., Zhou, Y., Duan, L., Li, Z., Eneji, A.E. and Li, J. (2010) Silicon effects on photosynthesis and antioxidant parameters of soybean seedlings under drought and ultraviolet- $\beta$ radiation. J. Plant. Physiol. 167, 1248-1252.

Siddiqui, M.H., Al-Whaibi, M.H., Faisal, M. and Al Sahli, A.A. (2014) Nano-silicon dioxide mitigates the adverse effects of salt stress on Cucurbita pepo L. Environ Toxicol Chem. 33, 2429-2437.

Singh, A. (2016) Varied Responses and tolerant mechanisms towards salinity stress in plants. Int. $J$. Plant. Soil. Sci. 11 (5), 1-13.

Tuna, A.L., Kaya, C., Higgs, D., Murillo-Amador, B., Aydemir, S. and Girgin, A.R. (2008) Silicon improves salinity tolerance in wheat plants. Environ. Exp. Bot. 62, 10-16.

Vaidyanathan, H., Sivakumar, P., Chakrabarty, R. and Thomas, G. (2003) Scavenging of reactive oxygen species in NaCl-stressed rice (Oryza sativa L.) differential response in salt-tolerant and sensitive varieties. Plant Sci. 165 (6), 1411-1418.

Van Bockhaven, J., De Vleesschauwer, D. and Höfte, M. (2013) Towards establishing broad-spectrum disease resistance in plants: silicon leads the way. J. Exp. Bot. 64, 1281-1293.

Vaughan, D. and Ord, B.G. (1981) Uptake and incorporation of ${ }^{14} \mathrm{C}$-labelled soil organic matter by roots of Pisum sativum L. J .Exp. Bot. 32, 679-687.

Walker, D.J. and Bernal, M.P. (2008) The effects of olive mill waste compost and poultry manure on the availability and plant uptake of nutrients in a highly saline soil. Bioresour. Technol. 99, 396-403. 
Wang, X.S. and Han, J.G. (2007) Effect of $\mathrm{NaCl}$ and silicon on ion distribution in the roots, shoots, and leaves of two alfalfa cultivars with two different salinity tolerance. Soil Sci. Plant Nutr. 53, 278-285.

Wolucka, B.A., Goossens, A. and Inze, D. (2005) Methyl jasmonate stimulates the de novo biosynthesis of vitamin C in plant cell suspensions. J. Exp. Botany, 56, 2527-2538.

Yamazaki, J., Ohashi, A., Hashimoto, Y., Negishi, E., Kumagai, S., Kubo, T., Oikawa, T., Maruta, E. and Kamimura, Y. (2003) Effects of high light and low temperature during harsh winter on needle photodamage of Abies mariesii growing at the forest limit on Mt. Norikura in Central Japan. Plant Science, 165, 257-264.
Yang, J.C. and Zhang, J.H. (2010) Grain-filling problem in 'super' rice. J. Exp. Bot. 61, 1-4.

Yang, C.M., Wang, M.H., Lu, Y.F., Chang, I.F. and Chou, C.H. (2004) Humic substances affect the activity of chlorophyllase. Chem. Ecol. J. 30, 1057-1065.

Yazici, I., Türkan, I., Sekmen, A.H. and Demiral, T. (2007) Salinity tolerance of purslane (Portulaca olerace $\mathrm{L}$.) is achieved by enhanced antioxidative system, lower level of lipid peroxidation and proline accumulation. Environ. Exp. Bot. 61 (1), 49-57.

Zúñiga, G., Argandoña, V.H. and Corcuera, L.J. (1989) Distribution of glycinebetaine and proline in water stressed and unstressed barley leaves. Phytochem.28, 419-420.

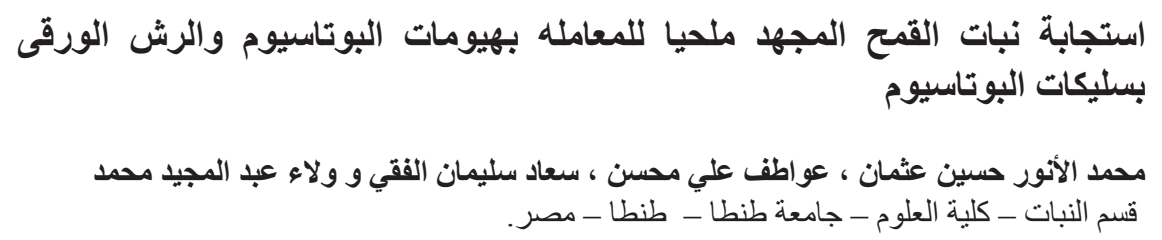

تعتبر الملوحه واحده من أهم أنواع الإجهاد الغير حيوي التي تقلل من إنتاجيه العديد من النباتات ومن

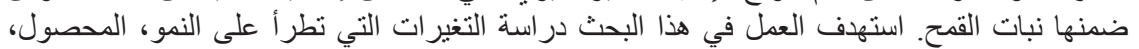

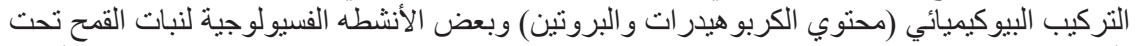

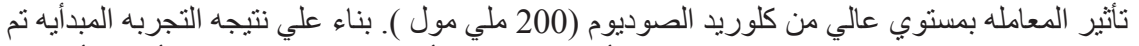
اختيار صنف جميز

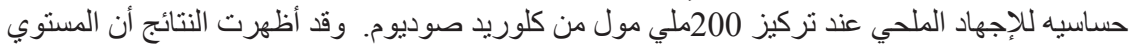

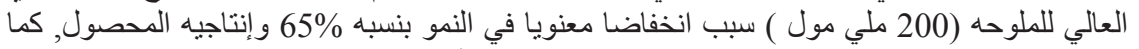

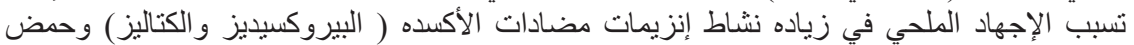

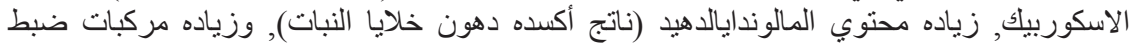

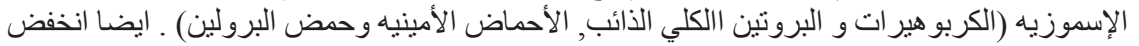

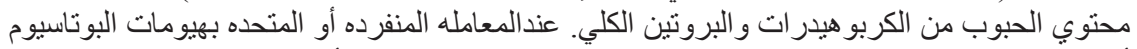

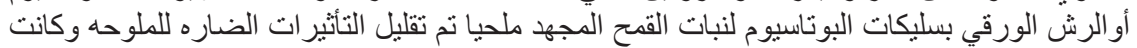

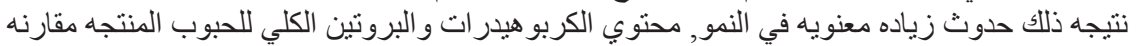

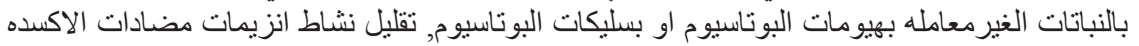

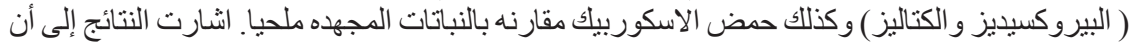

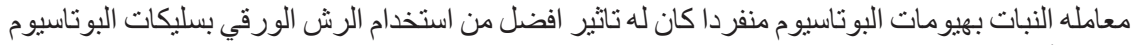

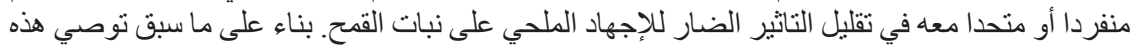

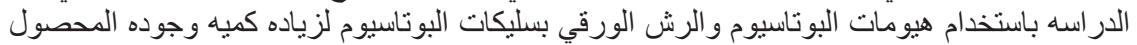
لنبات القمح المجهد ملحيا. 